
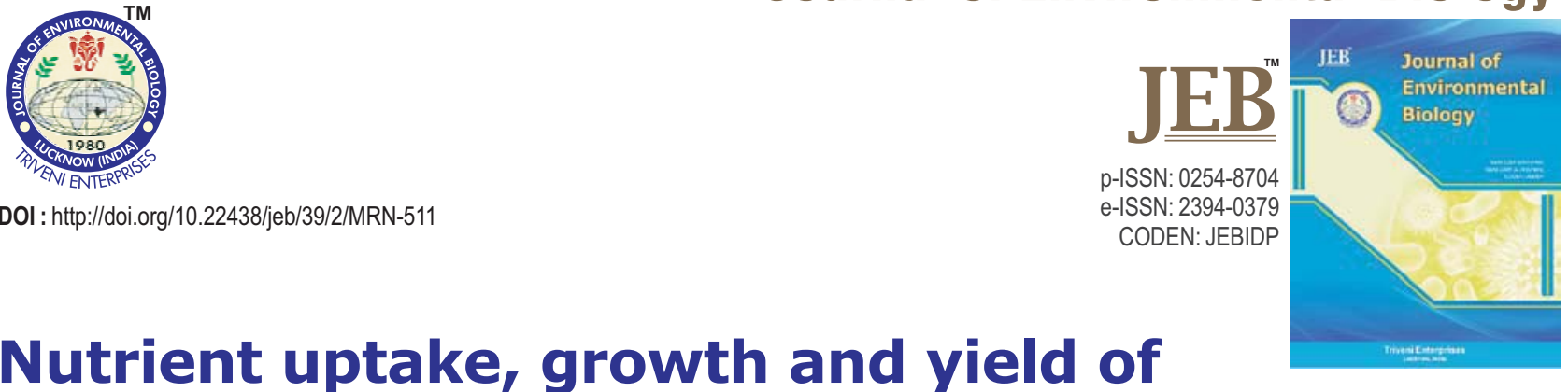

\title{
Nutrient uptake, growth and yield of pomegranate as influenced by irrigation frequencies under light textured soils
}

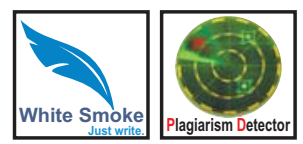

Authors Info

R.A. Marathe*, K. D. Babu and D.T. Chaudhari

ICAR - National Research Centre on Pomegranate, Solapur - 413 255, India

${ }^{*}$ Corresponding Author Email : ramarathe28@gmail.com

Key words

Cumulative irrigation Irrigation frequency Light textured soils Nutrient uptake Pomegranate

\section{Publication Info}

Paper received : 05.11.2016

Revised received : 07.02 .2017

Re-revised received: 02.06 .2017

Accepted: 04.08.2017

\section{Abstract}

Aim : In the arid ecosystem water supply is limited and it is imperative to adopt proper irrigation schedules to harvest more crop per drop of water. The main objective of the study was to investigate the impact of irrigation frequencies on performance of pomegranate grown under light textured soils of semi-arid regions.

Methodology : The study was carried out in newly planted pomegranate orchard grown in light textured soils. The treatments consisted of application of irrigation on every day and cumulative irrigation at 1, 2, 3,4 and 5 day interval. Leaf samples were analysed for macro- and micronutrient contents. Leaf temperature and chlorophyll content was estimated periodically. Plant vegetative growth and yield contributing characteristics were measured to relate with irrigation frequency.

Results : The leaf nutrient indicators like N, $\mathrm{P}, \mathrm{K}$ and $\mathrm{Fe}$ had more influence on vegetative growth of the plant during fruiting years.Irrigation on every alternate day maintained cool plant canopy as indicated by lowest leaf temperature during fruiting period. Highest leaf chlorophyll content (59.6), fruit yield (6.237 kg plant $\left.{ }^{-1}\right)$ and fruit quality in terms of highest juice recovery $(49.2 \%)$ and lowest juice acidity $(0.44 \%)$ were obtained on alternate day irrigation treatment. Fruit cracking to the extent of 21.3, 18.9 and $10.2 \%$ was observed in 5, 4 and 3 day interval treatments, respectively.

Interpretation : Plant performance in terms of vegetative growth, flowering, fruit yield and fruit cracking were influenced by irrigation frequencies. Due to low water retention capacity of light textured soils, cumulative irrigation should be provided at 1 day interval.

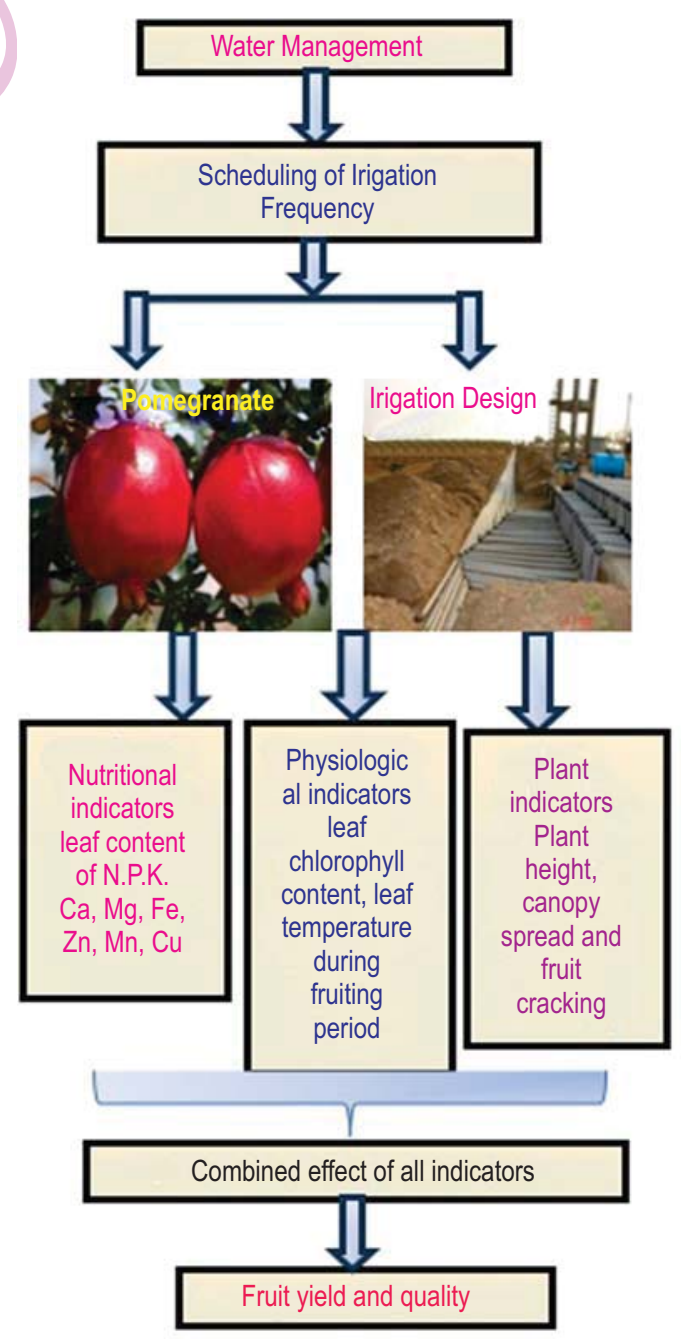




\section{Introduction}

Pomegranate (Punica granatum L.) is an important fruit crop of arid and semi-arid regions of the world. In India, the pomegranate cultivation reached to 1.31 lakh ha with an annual production of 13.45 lakh tonnes. Bhagwa is the predominant ruling variety grown in all the states of India due to its attractive red ring and bold sized, sweet red aril. Maharashtra contributes more than $70 \%$ of the total area under pomegranate cultivation followed by Karnataka, Gujarat and Rajasthan states having arid ecosystem. In these areas, it is cultivated on marginal lands with poor fertility, rocky land with shallow depth and low water holding capacity and excessive drainage (Marathe etal., 2016a).

In arid ecosystem, water supply is limited and it is imperative to adopt holistic strategies to harvest more crop per drop of water. Pomegranate withstand drought and moisture deficit (Jolikop and Kumar, 2000). But for optimum growth and quality fruit production, it is necessary to provide irrigation without causing hydric stress in the plants. The soils formed on Deccan plateau of central India have montmorillonitic mineralogy and very high water holding capacity. Generally farmers have tendency to apply huge quantity of water with large irrigation interval creating waterlogging conditions(Marathe et al., 2001) specially in surface layer having maximum feeder roots of pomegranate plants (Marathe et al., 2016b). This leads to imbalance in nutrient uptake thereby adversely affecting growth and flowering of pomegranate plants (Marathe et al., 2016).

The irrigation frequency, defined by interval between two successive irrigations should be used in a way so as not to compromise the water need of the plants in their different phonological stages (Sousa et al., 2014). Earlier some researchers have shown significant results under different irrigation frequencies on different crop like litchi (Lal and Kumar, 1997) and papaya (Jain and Tiwari, 2012) under different soil and climatic conditions. Application of water in small doses at frequent interval ensures their optimum utilization and higher crop yields. It also reduces percolation and evaporation losses, and improved water use efficiency by maintaining optimum soil moisture in the vicinity of the root zone.

In pomegranate, some information on irrigation requirement (Lawande and Patil, 1994) and irrigation method (Marathe et al., 2017b) is available but information on irrigation frequency is meagre. In this perspective, the present investigation was undertaken to evaluate the influence of different irrigation frequencies on growth and yield of pomegranate cv. Bhagwa orchards grown on light textured soils of semi-arid region of India.

\section{Materials and Methods}

Experimental site : The field experiment was conducted at National Research Centre on Pomegranate, Solapur, Maharashtra, located at $17^{\circ} 6^{\prime} \mathrm{N}$ latitude, $75^{\circ} 90^{\prime} \mathrm{E}$ longitude, at an altitude of $457 \mathrm{~m}$ amsl. The climate of the study area is semi-arid with hot summer and moderate winter with average annual rainfall of $694 \mathrm{~mm}$ occurring mostly during the months of JulySeptember.Average monthly maximum and minimum temperature during the experimental period (January to July) varied from 29.9 to $40.2^{\circ} \mathrm{C}$ and 15.2 to $25.1^{\circ} \mathrm{C}$. The daily pan evaporation ranged between 3.7 to $19.8 \mathrm{~mm}$. The field capacity $(33 \mathrm{kPa}$ ) and permanent wilting point (1.5 M Pa) of soil was 24.2 and $13.1 \%$, respectively. The soil of the experimental field was loamy with $15.8 \%$ coarse fragments, montmorillonitic mineralogy, $\mathrm{pH} 7.66$, electrical conductivity $0.18 \mathrm{dSm}^{-1}$, organic carbon $0.38 \%$ and calcium carbonate $6.24 \%$. The available $\mathrm{N}, \mathrm{P}$ and $\mathrm{K}_{2} \mathrm{O}$ content of surface soil was 190.0, 11.5 and $238.4 \mathrm{~kg} \mathrm{ha}^{-1}$, respectively.

Experimental design : The experiment was arranged in a randomized block design with 6 treatments, 4 replications having 2 plants per unit. The treatments consisted application of irrigation water at different irrigation frequencies viz. daily irrigation ( $\left.T_{1}\right)$, irrigation at 1 day interval $\left(T_{2}\right), 2$ days interval $\left(T_{3}\right), 3$ days interval $\left(T_{4}\right), 4$ days interval $\left(T_{5}\right)$ and 5 days interval $\left(T_{6}\right)$. For $T_{2}$ to $T_{6}$ treatments, the amount of water applied corresponded to the sum of ETc in the corresponding period. It means that the accumulated values of 2, 3, 4 and 5 days. The crop water requirement of pomegranate was computed on daily basis using the following equation (Mane et al., 2006):

$$
V=E_{p} \times K_{p} \times K_{c} \times S_{c} \times W_{p}
$$

where, $V=$ volume of water (liters per day per plant), $E_{p}=$ open pan evaporation ( $\mathrm{mm}$ per day), $\mathrm{K}_{\mathrm{p}}=$ pan coefficient, $\mathrm{K}_{\mathrm{c}}=$ crop coefficient, $S_{c}=$ crop spacing (plant to plant $x$ row to row in meter) and $W_{p}=$ wetting factor.

Irrigation efficiency of drip was considered as $90 \%$. The effective rainfall was calculated by balance sheet method from the actual rainfall received and was used for daily water requirement of crop. Irrigation was provided using drip system of irrigation, having four ( $4 \mathrm{lph}$ ) drippers placed on four sides of each plant at a distance of $30 \mathrm{~cm}$ during first year and $50 \mathrm{~cm}$ afterwards. Measured quantity of irrigation water was provided to the plants using water meters and separate pipeline for every treatment.Same amount of irrigation water was applied to the plants grown under each treatment.

Under water scarcity areas of Solapur, for pomegranate supplemental irrigation is required from December up to onset of rainfall during first week of July. Accordingly various treatments were imposed on one year old plants from $10^{\text {th }}$ February to $11^{\text {th }}$ June 2010. Due to severe infestation of bacterial blight disease, as a management practice, plants were cut to ground level during October 2010. All plant debris were literally swept from soil surface of whole farm and disinfected with bleaching powder spraying on soil surface. Again plants were allowed to grow and treatments were imposed from December 2011 to June 2012 and again during December 2012 to June 2013. During first year (2010) total amount 
of irrigation water applied to each plant was 500.9 I which increased to 1407.8 | during 2010-11 and 1639.6 I during 2012-13, respectively due to increase in plant canopy spread.

Leaf nutrient content : A representative leaf sample of 50 fully matured and expanded current season leaves located at the $8^{\text {th }}$ to $10^{\text {th }}$ position from apex were collected during each year(Marathe and Babu, 2015). The collected leaf samples were washed thoroughly in sequence with water, liquid soap, acidic water and glass redistilled water and dried in shade for four days followed by oven drying at $70^{\circ} \mathrm{C}$ till it achieved constant weight. The samples were digested (Chapman and Pratt, 1961) in di-acid mixture $\left(\mathrm{H}_{2} \mathrm{SO}_{4}: \mathrm{HClO} 4\right.$ in $\left.1: 2.5\right)$. Nitrogen was determined by using microkjeldhal steam distillation method, phosphorus by Vanadomolybdo phosphoric acid method, potassium by flame photometer and $\mathrm{Ca}^{2+}+\mathrm{Mg}^{2+}$ by versenate titration method. All micronutrients ( $\mathrm{Fe}, \mathrm{Zn}, \mathrm{Mn}$ and $\mathrm{Cu}$ ) were determined using atomic absorption spectrophotometer (Perkin Elmer, USA make AAnalyst 400). Soil moisture content was determined gravimetrically during fruiting period.

Growth, yield and fruit physico-chemical properties Vegetative growth in terms of plant height and plant spread was recorded in each year. Data on male and hermaphrodite flowers were taken by counting the flowers dropped on the ground and set on plants. The fruit yield data was recorded both in terms of number count and fruit weight basis during the year 2013. Cracked fruits were harvested separately and counted in terms of numbers. The harvested fruits were utilized for analysing physico-biochemical properties. Total soluble solids (TSS), acidity, juice content were estimated using standard procedures (AOAC, 1990).

Physiological parameters : Chlorophyll content in the leaf was measured using chlorophyll meter (KONICA MINOLTA SPAD$502)$ as indicated by SPAD values. A handheld infrared thermometer was used to measure leaf temperature of the plants during fruit development period. The data were taken from all sides of same plants, approximately $50 \mathrm{~cm}$ above the leaf at an angle of $30^{\circ}$ to the horizontal. Readings were taken between 13:00 and 15:00 hrs on sunny days.

Statistical analysis : The experiment was conducted in a randomized block design with each treatment replicated thrice. To detect the significant difference among different treatments, statistical analysis for shortest significant range tests was performed byTukey's HSD test using SAS (2011) software.

\section{Results and Discussion}

The scheduling of irrigation frequency had marked effect on leaf content of N (1.97-2.24 \%), $\mathrm{P}(0.12-0.18 \%), \mathrm{K}(0.57-0.75$ $\%), \mathrm{Cu}(72.5-103.7 \mathrm{ppm})$ and $\mathrm{Fe}(102.9-137.3 \mathrm{ppm})$ nutrients (Table 1). Amongst macronutrients, maximum leaf content of $\mathrm{N}$ and $\mathrm{K}$ was observed on 1 day followed by 2 day interval treatment, while $P$ in 2 day followed by 1 day irrigation interval treatment. These treatments were more effective owing to application of irrigation water at proper interval. Most of the nutrient absorption processes are aerobic in nature and periodical application of irrigation might have maintained good aeration in soil which resulted in higher uptake of these nutrients by the plants. The greater $\mathrm{N}, \mathrm{P}$ and $\mathrm{K}$ uptake with more frequent irrigation was reported earlier by Rad et al. (2011). Treatments involving application of irrigation after 3 to 5 days recorded significantly low nutrient content in leaves. In these treatments, application of higher amount of water might have favoured leaching of nutrients from the soil. Similarly, occurrence of low soil moisture content stress between two subsequent higher interval irrigations treatments favoured poor nutrient absorption by the plants. The findings in present study were in close conformity with the findings of Haneef et al. (2014) and Sharma et al. (2015) who reported decreased uptake of $\mathrm{N}, \mathrm{P}$ and $\mathrm{K}$ with lower soil moisture levels.

Daily irrigation treatment recorded maximum leaf $\mathrm{Fe}$ content (137.3 ppm) and $\mathrm{Cu}(103.7 \mathrm{ppm})$ which was significantly

Table 1 : Leaf nutrient content as influenced by different irrigation intervals

\begin{tabular}{|c|c|c|c|c|c|c|c|}
\hline \multirow{2}{*}{$\begin{array}{l}\text { Leaf } \\
\text { content }\end{array}$} & \multirow[b]{2}{*}{ Daily } & \multicolumn{4}{|c|}{ Irrigation interval } & \multirow[b]{2}{*}{5 Days } & \multirow{2}{*}{$\begin{array}{l}\text { Tukey's } \\
\text { HSD at } 5 \%\end{array}$} \\
\hline & & 1 Day & 2 Days & 3 Days & 4 Days & & \\
\hline $\mathrm{N}(\%)$ & $2.10^{\mathrm{ab}}$ & $2.24^{\mathrm{a}}$ & $2.19^{\mathrm{ab}}$ & $2.07^{\mathrm{ab}}$ & $2.06^{\mathrm{ab}}$ & $1.97^{b}$ & 0.25 \\
\hline $\mathrm{P}(\%)$ & $0.14^{\mathrm{ab}}$ & $0.17^{\mathrm{ab}}$ & $0.18^{\mathrm{a}}$ & $0.16^{\mathrm{ab}}$ & $0.13^{\mathrm{b}}$ & $0.12^{b}$ & 0.049 \\
\hline $\mathrm{K}(\%)$ & $0.69^{\mathrm{ab}}$ & $0.75^{\mathrm{a}}$ & $0.74^{a}$ & $0.64 b^{c}$ & $0.62 b^{c}$ & $0.57^{\circ}$ & 0.10 \\
\hline $\mathrm{Ca}(\%)$ & 1.53 & 1.63 & 1.75 & 1.88 & 1.94 & $1.9^{5}$ & NS \\
\hline $\operatorname{Mg}(\%)$ & 0.46 & 0.51 & 0.58 & 0.54 & 0.49 & 0.52 & NS \\
\hline $\mathrm{Cu}(\mathrm{ppm})$ & $103.7^{\mathrm{a}}$ & $95.1^{\text {ab }}$ & $72.5 \mathrm{c}$ & $91.6^{\mathrm{b}}$ & $88.5^{b}$ & $85.8^{b}$ & 11.9 \\
\hline $\mathrm{Zn}(\mathrm{ppm})$ & 25.4 & 26.0 & 30.8 & 28.2 & 27.5 & 26.5 & NS \\
\hline $\mathrm{Fe}(\mathrm{ppm})$ & $137.3^{\mathrm{a}}$ & $123.7^{\mathrm{ab}}$ & $116.0^{\mathrm{a}}$ & $115.4^{\mathrm{ab}}$ & $102.9^{b}$ & $107.0^{\mathrm{b}}$ & 22.6 \\
\hline $\mathrm{Mn}$ (ppm) & 58.4 & 56.0 & 61.4 & 56.9 & 57.9 & 55.1 & NS \\
\hline Chlorophyll (SPAD) & $56.0 b^{c}$ & $56.9^{\mathrm{ab}}$ & $57.5^{\mathrm{a}}$ & $55.9^{\text {bc }}$ & $55.4^{\circ}$ & $55.0^{\circ}$ & 1.39 \\
\hline
\end{tabular}

Means sharing a common letter within the column are not significant by Tukey's HSD test at $P<0.05$ 
Table 2 : Vegetative growth of plant as influenced by different irrigation intervals

\begin{tabular}{|c|c|c|c|c|c|c|c|}
\hline \multirow{2}{*}{$\begin{array}{l}\text { Plant vegetative } \\
\text { growth parameter } \\
\text { content }\end{array}$} & \multicolumn{6}{|c|}{ Irrigation interval } & \multirow{2}{*}{$\begin{array}{l}\text { Tukey's } \\
\text { HSD at } 5 \%\end{array}$} \\
\hline & Daily & 1 Day & 2 Days & 3 Days & 4 Days & 5 Days & \\
\hline \multicolumn{8}{|c|}{ Increase (\%) during February to October 2010} \\
\hline Plant height & $26.3^{\mathrm{ab}}$ & $30.6^{a}$ & $28.0^{\mathrm{ab}}$ & $27.8^{\mathrm{ab}}$ & $23.2^{b}$ & $23.0^{b}$ & 6.6 \\
\hline Average spread & 35.1 & 35.2 & 31.8 & 34.2 & 32.2 & 26.8 & NS \\
\hline \multicolumn{8}{|c|}{ Increase (\%) during December 2011 to July 2012} \\
\hline Plant height & $14.4^{\mathrm{b}}$ & $18.1^{a}$ & $15.2^{b}$ & $15.2^{b}$ & $14.1^{b}$ & $14.5^{\mathrm{b}}$ & 2.75 \\
\hline Average spread & $15.3^{\mathrm{ab}}$ & $17.6^{\mathrm{a}}$ & $16.9^{\mathrm{ab}}$ & $15.4 a^{b}$ & $14.6^{b}$ & $14.5^{\mathrm{b}}$ & 2.6 \\
\hline \multicolumn{8}{|c|}{ Increase (\%) during December 2012 to July 2013} \\
\hline Plant height & $17.0^{\mathrm{bc}}$ & $21.3^{\mathrm{a}}$ & $20.0^{\mathrm{ab}}$ & $19.0^{\mathrm{ab}}$ & $13.9 c^{d}$ & $13.1^{d}$ & 3.14 \\
\hline Average spread & $22.6^{\mathrm{bc}}$ & $27.8^{a}$ & $24.7^{\mathrm{ab}}$ & $20.8^{\text {cd }}$ & $17.2 d^{e}$ & $16.6^{e}$ & 3.77 \\
\hline
\end{tabular}

Means sharing a common letter within the column are not significant by Tukey's HSD test at $P<0.05$

Table 3 : Flowering, yield and quality of fruits as influenced by different irrigation intervals

\begin{tabular}{|c|c|c|c|c|c|c|c|}
\hline \multirow{2}{*}{$\begin{array}{l}\text { Yield parameters } \\
\text { (Per plant) }\end{array}$} & \multicolumn{6}{|c|}{ Irrigation interval } & \multirow{2}{*}{$\begin{array}{l}\text { Tukey's } \\
\text { HSD at } 5 \%\end{array}$} \\
\hline & Daily & 1 Day & 2 Days & 3 Days & 4 Days & 5 Days & \\
\hline Male flowers & 182.3 & 171.9 & 160.9 & 200.2 & 177.5 & 186.2 & NS \\
\hline Hermaphrodite flowers & $98.2^{b}$ & $108.0^{\mathrm{ab}}$ & $105.9^{\mathrm{ab}}$ & $120.9^{\mathrm{a}}$ & $115.4^{\mathrm{ab}}$ & $110.0^{\mathrm{ab}}$ & 20.4 \\
\hline Total number of flowers & 280.5 & 279.9 & 266.8 & 321.1 & 292.9 & 296.2 & NS \\
\hline Number of fruits & $29.0^{\mathrm{ab}}$ & $33.0^{\mathrm{a}}$ & $31.0 a^{b}$ & $25.0^{\mathrm{bc}}$ & $21.1^{\mathrm{c}}$ & $20.1^{c}$ & 6.78 \\
\hline Weight of fruits (kg) & $5.46^{\mathrm{ab}}$ & $6.23^{\mathrm{a}}$ & $6.06 \mathrm{a}^{\mathrm{b}}$ & $5.21^{\mathrm{b}}$ & $4.02^{c}$ & $3.41^{\mathrm{c}}$ & 0.88 \\
\hline Percent cracked fruits & $3.1^{c}$ & $0.3 c$ & $0.4^{c}$ & $10.2^{\mathrm{bc}}$ & $18.9^{\mathrm{ab}}$ & $21.3^{\mathrm{a}}$ & 10.4 \\
\hline Average wt of fruit (g) & 191.0 & 192.5 & 196.1 & 211.5 & 192.6 & $171^{9}$ & NS \\
\hline Fruit Juice (\%) & $47.8^{\mathrm{ab}}$ & $49.2^{\mathrm{a}}$ & $48.8^{\mathrm{a}}$ & $46.8^{\mathrm{abc}}$ & $44.9^{b c}$ & $43.7^{\circ}$ & 3.64 \\
\hline Juice acidity (\%) & $0.47^{\mathrm{ab}}$ & $0.44^{b}$ & $0.44^{\mathrm{ab}}$ & $0.48^{\mathrm{ab}}$ & $0.51^{\mathrm{ab}}$ & $0.52^{\mathrm{a}}$ & 0.08 \\
\hline TSS (OBricks) & $15.0^{\mathrm{ab}}$ & $15.2^{\mathrm{ab}}$ & $15.4^{\mathrm{a}}$ & $15.2^{\mathrm{ab}}$ & $14.9^{\mathrm{ab}}$ & $14.7^{\mathrm{b}}$ & 0.60 \\
\hline TSS/acid ratio & $32.1^{\mathrm{ab}}$ & $34.8^{\mathrm{a}}$ & $35.0^{\mathrm{a}}$ & $31.3^{\mathrm{ab}}$ & $29.3^{\mathrm{b}}$ & $28.6^{b}$ & 5.42 \\
\hline
\end{tabular}

Means sharing a common letter within the column are not significant by Tukey's HSD test at $P<0.05$

low in 3 to 5 days irrigation interval treatments (Table 1). Application of irrigation on each day created temporary water logging conditions in surface soil layers which might have resulted in increased availability and uptake by plants. Increased availability of micronutrients under high moisture conditions is attributed to low redox potential due to low oxygen and increased solubility of reduced form of iron $\left(\left(\mathrm{Fe}^{3}+\right.\right.$ to $\left.\mathrm{Fe}^{2}+\right)$ and other micronutrients in the soil (Marathe et al., 2009). Earlier, increased micronutrients concentration in the leaves of Nagpur mandarin under temporary waterlogging condition during rainy seasonswas reported by Marathe et al. (2003).

Chlorophyll content in the leaves of the plants, as expressed by SPAD values, significantly varied from 55.0 to 57.5 amongst the treatments (Table 1). It was highest in 2 day, followed by 1 day and daily irrigation interval treatments indicating better photosynthetic capacity of the plants, which might be due to better nutrient uptake and availability of ample water to the plants. Increased uptake of $\mathrm{Fe}$ in these treatments also plays important role in chlorophyll formation (Marathe et al., 2017). Increased contents of chlorophyll (38\%) and soluble sugar (8.5\%) in leaves due to alternated drip irrigation was reported earlier (Liu et al., 2016) in coffee trees. Drastic reduction in leaf chlorophyll content was recorded in 4 and 5 days irrigation interval treatments.

Leaf temperature recorded during fruit development period of March and April months varied from 97.7 - 101.1 and 100.3 - $103.5^{\circ} \mathrm{F}$ amongst the treatments (Fig. 1). The ambient temperature during these months were 106.0 and $114.5^{\circ} \mathrm{F}$, respectively. Leaf temperature, irrespective of frequency of irrigation was lower than air temperature in all the treatments and months. It increased with the increase in ambient temperature. Lowest leaf temperature was recorded in 1 day followed by daily irrigation treatment, which might be due to higher soil moisture content in soil layers providing maximum water for increased rate of transpiration, minimizing temperature of the leaves. Cool canopy was found to be an important physiological principle for tolerance to high temperature stress (Munjal and Rena, 2003). It was high in 4 and 5 days irrigation interval treatments indicating maximum stress conditions. In this treatment, as the 


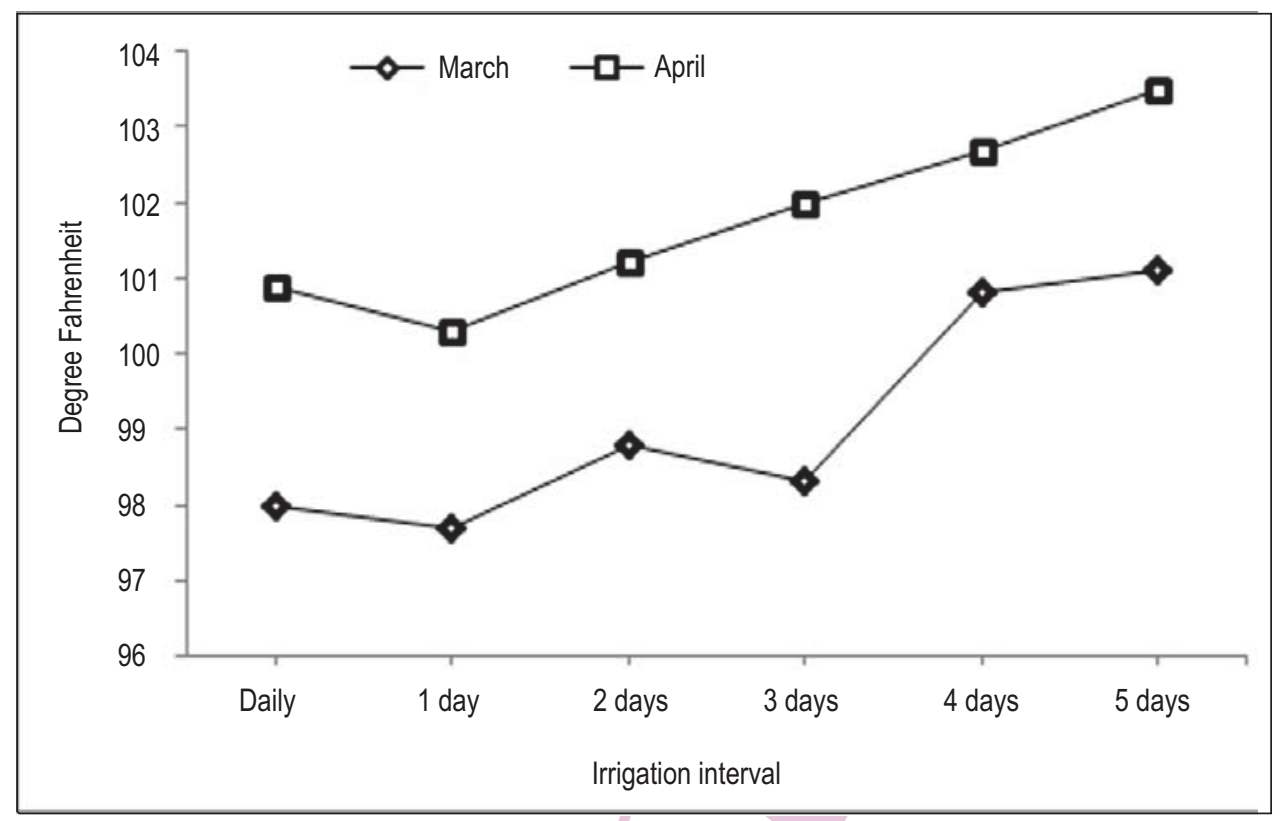

Fig. 1 : Leaf temperature as influenced by different irrigation intervals

soil water became limited, transpiration was reduced which increased the leaf temperature.

The scheduling of irrigation frequency had marked effect on the vegetative growth of the plants only during second and fruit bearing period (Table 2). During first year of plantation (2010), vigorous growth in terms of plant height (23.0 - 30.6\% over initial) and plant spread (25.1 $-41.2 \%$ over initial) was recorded in all treatments as compared to second year (2011-12) (14.1 - 18.1 and 14.5-17.6\%) and fruit bearing period (2012-13) (13.1 - 21.3 and $16.6-27.8 \%$ ). During initial year of plantation, irrigation frequency has little influence on growth parameters. Similar types of results were reported in pomegranate (Chopade and Gorantiwar, 1998) and fig (Andrade et al., 2014) where irrigation methods and frequencies did not have much influence on the plant growth during initial years. During the year 2011-12 and 2012-13, maximum increase in plant height and plant spread was observed in 1 day followed by 2 days irrigation interval treatment. The increase might be due to periodical supply of ample water to the plant. This maintains the soil moisture at optimum level eliminating water stress to the plants, which facilitated better nutrient availability and uptake resulted in greater plant vigour. These findings are in agreement with the results of Ouma (2005) who reported that increased irrigation frequency from 3 days to every day resulted in increased vegetative growth of Rough lemon plant.Plant growth was substantially low in 4 and 5 days irrigation interval treatments. The reduction was more pronounced during bearing period. In these treatments, application of high amount of water might have lost as percolation, and sufficient moisture availability was not maintained till subsequent irrigation, inducing moisture stress to the plants. This resulted in low nutrient uptake and leaf chlorophyll content adversely affecting growth of the plants. The treatment involving irrigation on every day was also not much effective in increasing plant growth. This practice tends to keep the soil in wet condition in effective root zone, thereby hampering aeration, nutrient uptake and plant growth. The results revealed that irrigation interval should be neither too low nor too high to attain maximum growth of pomegranate plants.

A critical stem in fruit production is the transition to and completion of flowering. Flowering intensity in terms of number of male, hermaphrodite and total flowers varied from 160.9 - 200.2, 98.2 - 120.9 and 266.8 - 321.1 flowers per plant, respectively amongst the treatments (Table 3 ). Hermaphrodite flowers were maximum in the plants irrigated after 3 days interval. In general, flowering intensity was high in higher ( 3 to 5 days) compared to less (daily, 1 and 2 days) irrigation interval treatments, which might be due to moisture deficit stress in plants. The present findings are in conformity with the findings of Sharma et al. (2015), Marathe et al. (2003) and Marathe et al. (2017a) who reported that soil moisture deficit promotes early and more intense flowering in mango, Nagpur mandarin and pomegranate, respectively.

Varying irrigation interval had significant effect on fruit yield and yield contributing parameters (Table 3 ). Total yield in terms of number and weight significantly varied from 20.1 - 33.0 and $3.41-6.23 \mathrm{~kg}$ per plant, respectively amongst the treatments. Highest fruit yield was obtained in 1 day irrigation interval treatment which was at par with 2 day treatment. The increase in yield in this treatment over 3,4 and 5 days interval treatment was $19.6 \%, 55.0 \%$ and $117.9 \%$, respectively. Such an increase could be attributed to maintenance of soil at optimum moisture condition which resulted in balanced nutrient uptake, better plant growth and least fruit cracking under these treatments. Drastic reduction in fruit yields under 3,4 and 5 days irrigation interval treatments were 
mainly due to severe fruit cracking $(10.2-21.3 \%)$. In these higher irrigation interval treatments, between two subsequent irrigations, low soil moisture content might have created frequent water stress as indicated by higher leaf temperature (Fig. 1) in the plants, especially at the time of fruit maturity resulting in cracking of fruits. Reduction in yield was also due to reduction in size and weight of fruits due to loss of turgidity due to soil water deficit in the rootzone of the plants (Jain and Tiwari, 2012).

Fruit quality in terms of fruit height, fruit diameter, rind thickness, percent fruit rind and percent fruit aril were not affected with irrigation interval treatments and the results were nonsignificant (Data not shown). However, fruit juice recovery (43.7$49.2 \%$ ), acidity of fruit juice $(0.44-0.52 \%)$, total soluble solids (TSS) (14.7-15.4 oB) and TSS / acid ratio (28.6-35.0) showed significant variation amongst the treatments (Table 3). Highest juice recovery and lowest juice acidity was observed in the fruits of the plants receiving irrigation at 1 day interval, while TSS and TSS:acid ratio in 2 days irrigation interval treatments. Treatments involving frequent irrigation ( 2 days followed by 1 day and daily) produced good quality fruits which might be due to optimum water supply to the plants at appropriate interval. Increased TSS and sugars as a result of frequent irrigation was reported earlier in case of sweet orange (Singh and Singh, 1981). Fruit quality was drastically reduced by higher irrigation interval treatments ( 3 to 5 days) mainly due to shrinkage and cracking of fruits.

It can be concluded that in pomegranate orchards grown in light textured soils, irrigation should be provided on every alternate day. Because of low water retention capacity of light textured soils, irrigation at and above 3 days interval, induced heavy fruit cracking adversely affecting fruit yield. Daily irrigation practice tends to keep the soil in wet condition, which should be avoided.

\section{References}

Andrade, I.P.S., D.F. Carvalho, W.S. Almeida, J.B.G. Silva and L.D.B. Silva: Water requirement and yield of fig trees under different drip management. J. Brazilian Asso. Agric. Eng.,34, 17-27 (2014).

AOAC: Official Methods of Analysis. Association of Official Analytical Chemists, Arlington, Virginia 22201 USA, pp. 17-19 (1990).

Chapman, H.D. and P.F. Pratt: Methods of analysis for soil, plants and water. Division of Agricultural Sciences, University of California, USA, pp. 182-86 (1961).

Chopade, S.O. and S.D. Gorantiwar: Effect of various methods of irrigation on growth and yield of pomegranate. Annals Plant Phys., 12, 98-102(1998).

Haneef, M., R.A. Kaushik, D.K. Sarolia, A. Mordia and M. Dhakar: Irrigation scheduling and fertigation in pomegranate cv. Bhagawa under high density planting system. Indian J. Hort.,71, 45-48 (2014).

Jain, P.K. and A. Tiwari: Effect of irrigation systems and frequencies on growth and yield of papaya. Indian J. Hort.,69, 277-280 (2012).

Jolikop, S.H. and P.S. Kumar: New fruit crop varieties for arid regions: Ruby (pomegranate) and Arka Sahan (custard apple). Indian Hort.,45, 19-20 (2000).

Lal, R.L. and G. Kumar: Effect of irrigation frequencies on yield and quality of litchi fruits cv. Rose scented. Indian J. Hort., 54, 10-15(1997).
Lawande, B.T. and V.K. Patil: Effect of different water regimes on growth, flowering and fruiting of pomegranate. J. Maharashtra Agric. Univ.,19, 220-223 (1994).

Liu, X., F.Li, Q. Yang and X. Wang: Effect of alternate drip irrigation and superabsorbent polymer on growth and water use of young coffee tree. J. Environ. Biol., 37, 485-491 (2016).

Mane, M.S., B.L. Ayare and S.S. Magar: Principles of drip irrigation system, Jain Brothers, New Delhi, pp. 24-87 (2006).

Marathe, R.A. and K.D.Babu:Determination of sampling period and leaf position for critical nutrient analysis in pomegranate cv. Bhagwa. Indian J. Hort.,72, 562-565(2015).

Marathe, R.A., A.A. Murkute and K.D.Babu:Mineral nutrient deficiencies and nutrient interactions in pomegranate. Natl. Acad. Sci. Lett.,39, 407-410 (2016).

Marathe, R.A., J. Sharma, A.A. Murkute and K.D.Babu:Response of nutrient supplementation through organics on growth, yield and quality of pomegranate. Sci. Hortic.,214,114-121 (2017).

Marathe, R.A., J. Sharma, Y.R. Shinde and D.T. Chaudhary : Standardization of organic manure application in pomegranate (Punica granatum)orchards grown in semi-arid regions. Indian $\mathrm{J}$. Agri. Sci., 86, 1265-1270 (2017a).

Marathe, R.A., K.D. Babu and D.T. Chaudhary : Response of pomegranate (Punica granatum) to drip irrigation systems in light textured soils of semi-arid regions. Indian J. Agri. Sci.,87, 56-61 (2017b).

Marathe, R.A., K.D. Babu and J. Sharma:Identification of suitable soils for cultivation of pomegranate (Punica granatum) cv. Ganesh. Indian J. Agri. Sci.,86, 227-233 (2016a).

Marathe, R.A., K.D. Babu, A.A. Murkute and D.T. Chaudhary : Root distribution pattern of pomegranate in different soil types. Indian $\mathrm{J}$. Hort.,73, 62-65(2016b).

Marathe, R.A., P.R. Bharambe, R. Sharma and U.C. Sharma : Soil properties of vertisols and yield of sweet orange (Citrus sinensis) as influenced by integrated use of organic manures, inorganics and bio-fertilizers. Indian J. Agri. Sci.,79, 3-7 (2009).

Marathe, R.A., S. Mohanty and S. Singh: Soil characterization in relation to growth and yield of Nagpur mandarin (Citrus reticulata Blanco). J. Indian Soc. Soil Sci.,51, 70-73 (2003).

Marathe, R.A., S. Mohanty and S. Singh: Waterlogging - as a soil related constraint to performance of Nagpur mandarin orchards. Agropedology, 11, 134-138 (2001).

Munjal, R. and R.K. Rana: Evaluation of physiological traits in wheat (Triticum aestivum L.) for terminal high temperature tolerance. Proc. Tenth Inter. Wheat Genetics Symp., Poestum, Italy, Vol. 2, Sec. 3, Classical and Molecular Breeding, pp. 804-805 (2003).

Ouma, G.: Root confinement and irrigation frequency affect growth of rough lemon (Citrus limon) seedlings. Fruits, 60, 195-202 (2005).

Rad, P.M.R., S.A.R. Movahedi Naeini and M. Pessarakli: Nutrient uptake, soil and plant nutrient content and yield components of wheat plants under different planting systems and various irrigation frequencies. J.Plant Nutr., 34, 1133-1143 (2011).

SAS: SAS Institute Inc. ver. 9.3., 2011 Guide Cary, NC, USA, ISBN 978-1 $-60764-895-6$ (2011).

Sharma, R., S.K. Pandey and T.A. Sharma: Influence of soil moisture on growth and nutrient content in healthy and malformed panicles of mango varieties. Indian J. Hort.,72, 133-138 (2015).

Singh, R. and R. Singh: Influence of irrigation frequencies on granulation and fruit quality in Valencia late sweet orange. Nat. Symp. Tropical and Sub-tropical Fruit Crops, Bangalore (1981).

Sousa, V.F., B.M. Azevedo, C.N.V. Fernandes, T.V.A. Viana and M.S.L. Silva: Growth, gas exchange and yield of peanut in frequency of irrigation. Revista Ciencia Agronomica, 45, $27-34$ (2014). 